\title{
Justice as Told by Judges: The Case of Litigation Over Local Anti-Immigrant Legislation
}

\author{
DORIS MARIE PROVINE \\ Faculty of Justice \& Social Inquiry, School of Social Transformation, Arizona State University, Tempe, \\ Arizona, USA
}

\begin{abstract}
In the absence of comprehensive immigration reform at the federal level, many American states and localities are undertaking their own legal reforms. The new state and local laws have been challenged by immigrant-rights organizations and individuals on the grounds that the federal government has already pre-empted the field. The lawsuits bring a new narrative voice - that of judges-into the boiling U.S. immigration debate. Judges engage the controversy over local enforcement of immigration enforcement, as they have other contentious disputes, both as pragmatic decision-makers and as spokespersons for justice. The tensions this dual role entails are explored here in the context of a single, controversial case. Close-up analysis of the judge's narrative strategy reveals a range of specific techniques to create moral distance from a decision, combined, ironically, with the enlistment of moral themes to justify the ruling. The inter-twining of rule-of-law and justice rhetoric mirrors and also shapes a broader politics of justice in the United States.
\end{abstract}

\section{Introduction}

The inaugural issue of this journal carried an interview with David Harvey in which he observed that ideas about justice had changed in his lifetime. In the 1970s, activists focused on what justice might look like in a better world because they were convinced that justice is sometimes achievable. That conviction has disappeared: "[I]njustice is what we talk about. We don't have a positive conception of justice; we have a negative conception of lack of justice-injustice. That is a very important mobilizing idea” (Pender, 2007, p. 16). Harvey's observation certainly fits the case of immigration policy. No one seems certain about how to achieve justice in immigration, but there is constant talk of the injustices of the current system. Those who would restrict immigration are as dissatisfied as those who advocate its expansion, which helps to explain why "comprehensive" immigration reform is so difficult to achieve in the United States and in other wealthy immigrant-receiving nations.

Correspondence Address: Doris Marie Provine, School of Transformation, Arizona State University, Tempe, Arizona, 85287-0403, United States. Tel: +1 480 965-7682, Email: Marie.Provine@asu.edu 
In the United States, municipalities and states have responded to the political vacuum and more dispersed patterns of immigrant settlement with their own initiatives. In 2008 state legislatures considered 1,562 bills and enacted 240 immigration-related laws on subjects ranging from eligibility for drivers licenses to sanctions for employers who hire persons without legal status (National Conference of State Legislatures, 2009). Many cities and towns have enacted their own legislation (Ramakrishnan \& Wong, 2007). Most of these laws are designed to make it more difficult for immigrants without legal status to work, acquire housing, or become eligible for educational or other benefits. At the same time, some local police forces are being asked or required to inform federal immigration officials when they encounter potentially unauthorized persons (Decker, Lewis, Provine, \& Varsanyi, 2009).

The rise of anti-immigrant legislation at this level has, not surprisingly, provoked litigation from those most affected, particularly employers and immigrants. The role that courts can play in the controversy is limited, but important for both pragmatic and ideological reasons. Judges have no power to rule on the wisdom or efficacy of legislation, but they can determine whether lawmakers are acting within their proper scope of authority in creating law, and they decide who can sue for relief from its strictures. For state and local governments, the principal issue is whether they can step into the perceived gap in the current federal framework and adopt their own regulatory statutes and ordinances. Those who challenge these laws must show that they have suffered a sufficient degree of harm, a complex issue when the complainant is without legal status to remain in the country.

While the ultimate impact of these legal challenges remains uncertain, it is clear that a new voice has been added to the sharp political debate over unauthorized immigrants and their rights. Judges speak to these issues with a distinctive approach. The stories they create in their opinions begin from the premise that justice can be achieved through the proper application of the rule of law. Although most would admit that justice is not always achieved, the prevailing view is that justice is most likely to be achieved through high quality lawyering and competent judging focused on the rule of law. This collective conviction that justice is within reach is the very quality that David Harvey found lacking in contemporary public debate. Judicial decisions thus merit attention as a distinctive species of justice talk, even apart from their practical impact.

For critical legal scholars, the relationship between law and justice is much more problematic (see e.g. Delgado, 2007; Fitzpatrick \& Tuitt, 2004; Kairys, 1998; Unger, 1996). From a critical perspective, judicial opinions memorialize a kind of victor's justice in which alternative voices are either muffled or absent. In this view, judicial decisions are hegemonic in their claim of final authority, but they hide the exercise of power involved by claiming to rely only on abstract principle that is neutrally derived from precedent and other binding authority. Law, in other words, hides its prejudices, and its violence, by clinging to its formality (Cover, 1985; Fish, 1991). So, from a critical perspective, the debate over whether judges are "activist" or not begs the question-all judging is an exercise in power, and judgment often provides a rationale for the powerful to remain that way. To claim the process is a search for justice is to place a conceptual fig leaf over a political process. 
But for judges, maintaining the fiction of a decision's inevitability is not a matter of individual proclivities - it is an occupational requirement. Every judicial opinion necessarily has both pragmatic and ideological goals. At a pragmatic level, the judge's narrative must provide a history of the dispute, review the legal process involved, and defend the result reached. At an ideological level, the narrative must subtly re-frame the controversy to fit within a relatively narrow rule-of-law framework. By creating a sense of the inevitability of the result, the judge implicitly suggests that justice has been done. Appeals to justice may also be more direct, but they will always rest within a legal frame. A judge who appealed to moral principle in deciding a case would blur the carefully constructed boundary between law and justice (Sarat, 2004, p. 93). Judges write judicial opinions, in short, to dampen conflict and enhance the legitimacy of the judicial process through story telling. In the Anglo-American context, that is a judge's job (see e.g. Powell, 2008).

In attempting to separate law from moral impulses and from social context, judicial narratives implicitly assert that the two can be separated, and should be, at least in the context of litigation. This professional project has been successful, so successful in fact that Americans often rely on judicial opinions to trump moral arguments. The professional project, however, has not been entirely successful. Empirical research on satisfaction with courts indicates that, while the public expects justice that is blind to a judge's personal preferences, litigants also expect judges to be realistically engaged in the dispute at hand (Ewick \& Silbey, 1998; Merry, 1990; Nielsen, 2000; Shiffrin, 1989; Tyler, 2006). Conley and O’Barr (2006), for example, note the widespread expectation among law's consumers that it will reflect a reasonably attentive response to social problems, and the disappointment that people experience when the process proves unresponsive: "Scholars are discovering that citizens come to the law seeking a holistic response to their social problems, and go away unhappy when it insists on its institutional isolation” (p. 871).

Such expectations among non-professionals suggest a paradox that cannot easily be resolved. On the one hand, Americans are comfortable with the idea of conceptualizing justice in legalistic terms, and used to relying on courts to resolve difficult moral issues. De Tocqueville (1835/2003) noted the American citizen's reliance on law and fascination with courts early in 1835 after he toured the U.S. But this tendency has a serious downside. When ordinary Americans believe that justice issues can be neatly resolved through legal analysis, they will abstain from more encompassing and searching debate. It is important to understand that judicial opinions intentionally avoid confronting moral concerns directly and intentionally narrow the scope of concern. Public debate over contentious issues like immigration enforcement should be more open to moral concerns, and more broadly based.

But how do judges construct inevitability in their decisions? Discovering these narrowing techniques requires close analysis. The ideal vehicle for studying the process is a single, controversial case, because this is the most difficult type to depoliticize. The strategy of decision and the specific tactics deployed should be relatively easy to spot in this context. The case examined here, Lozano v. Hazleton, is appropriately contentious and well known, particularly to people who follow news about immigration. ${ }^{1}$ The suit involves Hazleton, Pennsylvania, a small town that in 2006 adopted legislation designed to discourage settlement by unauthorized immigrants. The local ordinance was one of the first of its kind, and partly for that reason, became a test case in the debate over the power of localities to devise their 
own rules for deflecting unauthorized immigrants. Within a year, according to the Migration Policy Institute (2007), approximately 90 localities had proposed more than 100 similar ordinances, and at least 35 had passed.

\section{Judging as a Political Act}

The link between an individual judge and the decisions he or she reaches has long fascinated political scientists and historians. How does this literature bear on the issue of morality in judging? In political science, there is a very substantial academic literature linking judicial decisions to beliefs and attitudes, usually through aggregate analysis of votes on an appellate bench. These studies suggest the connection between personality and behaviour, treating decisions themselves as little more than justifications for previously held beliefs. Such findings could be read to lend support to the argument that judges are too "activist," that is, too willing to bring moral concerns to bear in reaching their decisions (Lipkin, 2008; Provine, 2005). What is important to note, however, is that judges themselves firmly reject this whole approach to their work. Judges consider the "activist" label either as an insult or as a serious misunderstanding of their devotion to the core principle that law alone determines the outcome of adjudication (see e.g. O’Scannlain, 2009). “Judicial activism" was a lay term for a lay audience that has found traction in politics, but not in the legal profession (Kmiec, 2004).

The legal profession appears to be devoted to the fiction that judges are mere oracles of the law. Law students learn how to pluck rules of law from judicial opinions, to be deployed as needed. The role of moral ideas in the legal process remains unproblematized and suspect in legal education. As Austin Sarat (2004) observes: "Law schools generally try hard to undo the naïve, innocent impulses of their entering students, in particular their impulse to think about law in moral or political terms.... The goal of professional education remains constant - to sever the connection between the question of what is good and right and what the law permits or prohibits” (p. 87). Legal practice reflects this same preoccupation with techniques for manipulating rules and suspicion of moral argumentation. Lawyers may litigate an issue with an eye to moral sentiments, but they do so strategically, engaging in an outcome-oriented politics of law to achieve their goals (Scheingold 1974, Sarat 2004). This is not to say that lawyers are unmoved by moral conviction. Cause lawyers, for example, promote their vision of justice through litigation (Epp, 1998; McCann, 2006; Sarat \& Scheingold, 2001. But for purposes of law practice and litigation, law and morality remain quite separate.

Judges carry this professional project forward in their opinions. As Cass Sunstein (1996) notes, it is their goal to attempt to resolve cases without taking sides (p. viii). The legal rules to be applied must emerge from the law, not from the judge, reflecting the baseline principle of blind justice. The use of the first person must be avoided. Fulsome citations to precedent are standard because they demonstrate reverence for authority and help to diffuse the reality of individual authorship. Facts must be linked to these legal rules in a way that suggests the inevitability of the decision reached. The judge, in other words, must appear to be above the 
controversy, but immersed in law. To a critical reader, the judicial narrative is a study in judicial modesty cloaking the exercise of real power.

A case like Lozano $v$. Hazleton, which challenges the power of a local community to determine its own destiny, puts judicial narrative skills to a difficult test. Will the court uphold the rights of persons without a legal right to remain against the wishes of local citizens, as expressed through their elected representatives? Immigration has always been an emotional issue, "a powerful and elemental leitmotif of American national development," according to Daniel Tichenor. He suggests that Americans are perhaps distinctive among citizens of countries of immigration in "the degree to which they have woven immigration narratives and iconography into their collective cultural identity" (Tichenor, 2002, p. 871).

The case law concerning the power of localities to restrict unauthorized immigrants was sparse when the ACLU and other groups and individuals filed their challenge to the Hazleton ordinance. This created a significant legal problem for Judge James M. Munley, the federal district judge in the Pennsylvania Middle Federal District Court who was assigned to decide the case. There were no Supreme Court precedents directly on point. Those that were most relevant focused on other issues, or were old and predate current federal legislation. Nor had the intermediate appellate courts taken a clear stand.

The situation has changed only slightly since then. Other federal district courts are beginning to weigh in on the issue, and at least three of them have reached decisions sharply at variance with Judge Munley's decision in the Hazleton case (see e.g. Preston, 2008). Several of these cases have resulted in appeals, but decisions had not been reached in any of them at the time of this writing, including an appeal filed by Hazleton in this case. ${ }^{2}$ An indication of the lack of available guidance from appellate courts can be seen in discussions that are occurring in some state and local legislative bodies. Representatives are being pressured to enact restrictive laws, but they have become wary of the costs of defending these laws. Riverside New Jersey rescinded its Hazleton-type ordinance, citing the fiscal burden of defending it (Migration Policy Institute, 2007). Indiana received so much conflicting advice from legal experts about the constitutionality of its own proposed employer sanctions law that it moved the topic to a study committee after a September 2008 hearing (Kelly, 2008).

\section{Hazleton Takes a Stand}

The Hazleton City Council took decisive action against unauthorized immigrants working or residing in Hazleton on July 13, 2006, when it enacted the initial version of its Illegal Immigration Relief Act. A number of revisions and additions followed during August and September. In the final version, employers were required to check the immigration status of those they wished to hire. Failure to do so would result in loss of one's business license for five years. Landlords were also affected. Renting to persons without legal authorization to remain in the United States could result in a $\$ 1000 /$ day fine. The new legislation also declared English to be the city's official language; city employees were required to get official permission to translate any document.

Mayor Louis J. Barletta, grandson of an immigrant, drafted this legislation. He wore a bulletproof vest to the Council meeting that considered the proposals in order 
to suggest a connection between undocumented immigration and violent crime, a connection not evident in the local crime statistics. ${ }^{3}$ Mayor Barletta's opposition to undocumented immigrants and his advocacy for local action made him a media celebrity and gave him visibility in Washington and in immigration forums in other locations. ${ }^{4}$ His vows to make Hazleton "the toughest place on illegal immigrants in America” netted him many favourable emails and donations to a web site, Small Town Defenders. ${ }^{5}$ He ran for Congress in 2002, 2006, and again in 2008, losing in a close election against the long-time incumbent, Paul Kanjorski. Mayor Barletta's strong support for the Hazleton ordinance may also have helped him gain re-election as the city's mayor. The issue, Barletta argued, is not at all racial - he claimed to "love" "his" legal immigrants. It was the undocumented immigrants who threatened Hazleton's peace, security, and way of life. With the influx of undocumented immigrants, he mused, "I've lost my city” (Powell \& Garcia, 2007).

Not surprisingly, Hazleton's new law drew national attention. A lawsuit soon followed challenging the city's right to control work and living opportunities on the basis of legal status. The lawsuit was brought by a coalition of immigrants and supportive civil-rights organizations against Hazleton's mayor and council, who were defended by their own group of lawyers. The case turned on two issues. The preliminary question, which had to be answered in the affirmative for the case to continue, was whether persons without legal status to remain in the United States could nevertheless be heard in its courts to complain about legislation directed against their continued residence, and whether they could proceed anonymously. The plaintiffs, once they established their right to be heard, were asking the court to decide that Hazleton had exceeded its law-making power, pre-empting a role reserved for the federal government.

Hazleton's new law sparked a trend. Four neighbouring Pennsylvania municipalities and one in New Jersey quickly passed identical ordinances. Other communities both near and far began to consider them. The trend, which has since become nationwide, appears to be centered in small cities and towns across the United States, rather than in most major cities. Passions about immigration are most likely to be aroused, Powell and Garcia (2007) observe, "not in the urban megalopolises, but in small cities and towns, where for the first time in generations, immigrants have made their presence felt” (p. 1).

\section{Hazleton}

Mayor Barletta was correct in claiming that immigration had transformed his city. In 2002 Hazleton, with 22,729 residents, was nearly 95 percent white. Wages and educational levels were below national averages. ${ }^{6}$ But at about that time Puerto Ricans and Dominicans from the New York/New Jersey area began to arrive, attracted by jobs and the low cost of living. ${ }^{7}$ Cargill Meat Solutions, a meat-packing plant, opened in 2002, offering employment to approximately 1000 people, about 600 of whom were Latinos. The new Latino residents helped the town grow to 31,000 people, while the non-Hispanic population declined slightly (Powell \& Garcia, 2007). The county became one of the fastest-growing Latino destinations in 
the United States. This influx of new residents increased the vitality of a central city that had been hurt by economic decline.

This was not the first time that Hazleton has been transformed by immigration. The discovery of anthracite coal in the 1830s helped the tiny town grow into a small city by giving employment to a diverse population of Poles, Italians, Irish, and other European immigrants. ${ }^{8}$ Manufacturing came later, fuelling the economy as coal declined. During World War II Hazleton was a boomtown because of its production of silk parachutes used in war-time. Its population was 38,000 in 1940. The city had steadily declined in size until Cargill's arrival. These changes occurred in a place that is relatively isolated from major urban areas. The nearest neighbours are WilkesBarre, Allentown, and Scranton, Pennsylvania. Philadelphia lies nearly $100 \mathrm{~km}$ to the southeast. Hazleton, nestled in the foothills of the Pocono Mountains, has made a virtue of its rural character. The city's web page describes its golfing, fishing, hiking and biking in glowing terms as key elements in its quality of life.

\section{The Lawsuit}

On August 15, 2006, after a failed settlement attempt, a coalition of Hazleton residents, local businesses, and community organizations filed suit in federal court to block the "Illegal Immigration Relief Act." 9 Two national organizations, the American Civil Liberties Union and the Puerto Rican Legal Defense Fund, represented the plaintiffs, along with a coalition of individual attorneys and locally based organizations. The Immigration Reform Law Institute, the Mountain States Legal Foundation, and several private attorneys represented Hazleton. Three organizations, including the US Chamber of Commerce, filed amicus briefs. It was clear that this was going to be a big case and that it would be appealed, no matter what the result. The decision at the trial level would nevertheless determine the facts of the case and a working framework for decision. Appellate courts must respect the lower court's evaluation absent a manifestly incorrect resolution of the legal issues.

Judge James M. Munley scheduled two weeks for the trial, which began on March 12, 2007. A 70-year-old Pennsylvanian who had remained in the state through college, law school, law practice, and twenty years as county judge before becoming a federal judge in 1998, his ties to the locality could not have been stronger. Judge Munley was not only an experienced judge, but also a law teacher and author of several articles. His 206-page opinion in Lozano v. Hazleton reflected his zest for writing and devotion to clarity.

\section{The Right to be Heard}

Hazleton strongly contested the right of the plaintiffs to bring the case to court. The plaintiffs, a coalition of immigrants with and without authorization remain in the United States and organizations supporting them, sought a permanent injunction against enforcement of the city's Illegal Immigration Relief Act. How, the City asked, could anyone without the right to be in the United States complain about this legislation? And what stake did persons with legal status have in pursuing litigation? 
A decision that these plaintiffs had no "standing to sue" would quickly bring the case to a close.

The "standing” issue occupied nearly half of Judge Munley's opinion. He began by reciting US Supreme Court precedents requiring that the plaintiff allege "such a personal stake in the outcome of the controversy" as to justify judicial intervention. ${ }^{10}$ He then described the injury sustained by each plaintiff, and granted all but one pair of them the right to proceed (Lozano v. Hazleton, 16-18). Judge Munley rejected defendant's contention that these immigrants, because they were not legally present, have no grounds for complaint. Immigrants, he responded, even those currently without papers authorizing their stay, are not necessarily illegally present in the United States. The matter remains indeterminate until an appropriate legal official has ruled on the matter (43). It was legally irrelevant that some of these immigrants believed that they were "illegal" because they are not qualified to make that judgment.

Judge Munley reinforced the point by caricaturizing the City's position:

This argument appears to be a species of argument often heard in recent discussions of the national immigration issue: because illegal aliens broke the law to enter this country, they should not have any legal recourse when rights due to them under the federal constitution or federal law are violated. We cannot say clearly enough that persons who enter this country without legal authorization are not stripped immediately of all their rights because of this single illegal act (43-44).

He reminded the City that the $14^{\text {th }}$ Amendment offers its protection to "persons," not just citizens.

There are several noteworthy elements of a law-based theory of justice in this part of the opinion. First, Judge Munley repeatedly deflected attention from his own role as the sole judge in this case by consistently referring to himself as "we" and by using the passive voice ("recognized by law"). Even in this passive form, the court decides nothing - it "finds" the results it announces. Judge Munley also took the opportunity to reassert the pre-eminence of law by reframing the term "illegal immigrant.” Whether or not an immigrant is legally present, Judge Munley reminded his audience, can only be decided by a competent legal authority. That some of the parties to the dispute characterize themselves as "illegal immigrants" is legally irrelevant. More significantly, Judge Munley asserted the relevance of higher law, the U.S. Constitution, in resolving this dispute.

\section{The Protection of Anonymity}

The City of Hazleton also objected to allowing some of the plaintiffs to proceed anonymously. Anonymous litigation is not strictly prohibited in American jurisprudence, but it is generally discouraged by the Federal Rules of Civil Procedure and by traditions of vigorous advocacy. The City alleged that the unnamed plaintiffs did not follow requirements in seeking an exception, nor did they qualify for one. In letting them proceed as "John Doe" plaintiffs, the defendants asserted, the court (i.e. Judge Munley) was affirming and supporting evasion of US law. The judge 
responded to this attack in his usual passive, third-person style: "We find no merit to the defendant's arguments, but we shall address them all” (59).

The judge's discussion of the anonymity issue began, not surprisingly, with a recitation of relevant authority, including nine factors found by other courts to weigh in favour or against the use of pseudonyms by plaintiffs. He also felt obliged to discuss a case relied upon by the City, Jane Doe $1 \mathrm{v}$. Merten, in which a federal district judge had denied undocumented immigrant students the right to proceed anonymously. The students were contesting a Virginia law that prohibited undocumented immigrants from admission to state universities. ${ }^{11}$ Judges have a procedure for handling such situations: A decision at the same level cannot be "controlling," but it should be considered "persuasive authority"-if it is "on point" and "correctly decided." Judge Munley thus had two options: to "distinguish" Merten as inapposite to the current case, or to criticize it as incorrectly decided. He chose to "distinguish" Merten:

Unlike Merten, where plaintiffs were seeking admission to state colleges
and universities, the plaintiffs in this case do not seek to receive any goods
provided by the state. Further, their immigration status does not determine
whether they will be subject to the terms of the ordinance. Accordingly,
the individual identities and interests of the plaintiffs are not at issue in
this case to the degree they were in Merten and are not necessary to reach
the issues of constitutionality raised by the lawsuit. The intense public
interest in this case makes the risks from exposing sensitive information
about one's identity exponentially more dire than in Merten and make
more persuasive plaintiffs' reasons for seeking to proceed without
revealing their true names (66-67).

At this point Judge Munley turned to the facts of the case before him. He detailed threats received by persons associated with the case, and described fights that had broken out the night the city council adopted the Illegal Immigration Relief Act. Even US citizens associated with the case, Judge Munley noted, had faced "public condemnation and confrontation" (73). The rich description of these details stands out in an opinion otherwise devoid of context. The details work to defend the judge's decision regarding anonymity, and they reinforce the sense that, if this dispute were not heard by a court of law, it would be decided in the streets. Yet nowhere in this discussion does Judge Munley betray any sign that his own sense of justice and decent conduct has been offended. Nor did he infer any improper motive in the defendant's demand that all of the immigrant plaintiffs identify themselves: "We have no evidence to indicate that defendant adopted this position for illegitimate reasons" (81).

His final point, however, was subtly condemning. Judge Munley again repeated the defence charge that he was recognizing and affirming evasion of the laws in allowing undocumented plaintiffs to proceed anonymously. His response to this direct, and grave, attack was to invoke the founding principles of our nation:

A venerable principle of constitutional law holds that all persons in the United States have rights under the Fourteenth Amendment to the United States Constitution, whether they are citizens or not.... Allowing the Doe plaintiffs to proceed anonymously in the unique conditions of this case would not reward them for evading the country's immigration laws. It 
would instead provide them an opportunity to secure the rights guaranteed them by the Constitution of the United States (83-85).

The exchange between the defendants and Judge Munley illustrates how depersonalization can defuse conflict, even within the confines of a case. The defendants couched their assertion of an ethical lapse in institutional terms, referring to "the court" rather than the judge by name. Judge Munley's response was similarly impersonal. But this exchange went further. Judge Munley invoked the U.S. Constitution to drive home his argument. In so doing, he reached for a higher-law principle, aligning his position with long-accepted principles of justice as embedded in the Fourteenth Amendment's guarantee of due process of law. He further intimated that all individual rights protected by the Constitution are guaranteed, not on the basis of citizenship, but on the basis of personhood.

\section{Hazleton's Right to Regulate Undocumented Immigration}

The sections that deal with Hazleton's power to restrict the employment and housing of undocumented persons constitute most of the second half of the opinion. This part is replete with citations to case law but almost devoid of references to the local context. The issue was whether Hazleton had overstepped its powers, intruding upon the federal government's traditional superior, or plenary, power in matters related to immigration. The federal level, in other words, holds the trump cards, and when it chooses to play them, it takes precedence. The procedures Hazleton had created, according to the plaintiffs, also violated constitutional guarantees of due process, equal protection, and privacy. In addition, the plaintiffs contended, Hazleton had exceeded its powers under Pennsylvania law. Judge Munley considered each element of these claims in turn, methodically laying out the arguments and the relevant case law and announcing his decision on each element.

The initial question was whether there was any room for local employer-sanctions ordinances after Congress had created its own regulatory scheme in the Immigration Reform and Control Act of 1986 (IRCA). Hazleton wanted to avoid a head-on collision with the federal law, so it followed the federal law's basic framework, but imposed its own penalty for non-compliance: suspension of the offending company's business permit. (The federal statute, on the other hand, imposed fines and criminal sanctions.) It is not very clear from IRCA's language how much discretion remains at the local level. IRCA states: "The provisions of this section pre-empt any State or local law imposing civil or criminal sanctions (other than through licensing and similar laws) upon those who employ or recruit .... unauthorized aliens" (Section 1324a(h)(2)).

Judge Munley decided against Hazleton. He noted that the city had developed, not just its own sanction, but its own standard for behaviour: "Under Hazleton's interpretation of the provision, a state or local municipality properly can impose any rule they choose on employers with regard to hiring illegal aliens” (96). Then he moved to the penalty issue, referring to the city's provision for suspending a violator's business license as the "ultimate sanction." The wording suggests a kind of entrepreneurial death penalty. Building on this idea, Judge Munley argued that 
Congress could not have intended to allow localities to have such a weighty sanction: "It would not make sense for Congress in limiting the state's authority to allow states and municipalities the opportunity to provide the ultimate sanction." So, the judge concluded, Hazleton's sanction could not stand: "Such an interpretation renders the express pre-emption clause [of the federal law] nearly meaningless” (ibid.).

To someone unfamiliar with legal argument, it might seem odd that the judge found support for his point in a Supreme Court decision that had ruled against unauthorized immigrants. The case, Hoffmann Plastics Compounds, Inc. v. NLRB (535 U.S. 137 (2002)), involved the right of these immigrants to join a union. They lost because the Supreme Court gave priority to the federal government's interest in controlling employment of unauthorized immigrants over the federally protected right to organize (147).

Plaintiffs had achieved the victory they sought. Judge Munley nevertheless felt compelled to discuss several variants on the pre-emption issue, "for purposes of completeness." He used this discussion to demonstrate the intricacy of the federal regulatory approach, and the federal government's long-standing interest in employment. The effect was to bolster his decision by suggesting how employers might find themselves "betwixt and between" federal and local regulations.

Hazleton's effort to discourage apartment rentals to undocumented tenants also failed under the weight of federal pre-emption and other constitutional defects. The rental ordinance required a verification process designed to prevent landlords from "harbouring" unauthorized aliens. Hazleton had erred, Judge Munley ruled, in assuming that all unauthorized aliens are deportable (128). Federal officials sometimes give unauthorized immigrants residency status, he noted, and aliens have procedural rights in this determination. No state or locality could possibly know who might ultimately be allowed to stay. In support of his position he drew on Justice Blackmun's concurrence in Plyler v. Doe: “The structure of the immigration statuses makes it impossible for the State to determine which aliens are entitled to residence, and which eventually will be deported." ${ }^{12}$ Hazleton, like the Texas school authorities in Plyler, was interfering with a well-calibrated federal administrative structure.

The entire discussion proceeded as if there was a clear path through the forest of precedents and statutes cited by the litigants. To find that path, all that was required was careful legal analysis. There was no discussion of the one inconvenient political fact that brought about this controversy. Hazleton had acted because federal law was widely perceived to be ineffective in discouraging employers from hiring unauthorized immigrants. Legally speaking, it was irrelevant whether city leaders had been motivated by high-minded concerns for local workers with legal status or by calculations of base political advantage arising out of fear of newcomers. Motivation is sometimes, but not always, relevant in law, a reminder that legal forums often can define their own scope of inquiry and concern.

Justice concerns, however, found their way into Judge Munley's narrative at several points. He returned to this theme near the end of his opinion, focusing on the high ideals of the U.S. constitution, while subtly disparaging Hazleton for using its law-making power to harm a "disfavoured group":

The genius of our Constitution is that it provides rights even to those who evoke the least sympathy from the general public. In that way, all in this nation can be confident of equal justice under its laws. Hazleton, in its zeal 
to control the presence of a group deemed undesirable, violated the rights of such people, as well as others within the community. Since the United States Constitution protects even the disfavoured, the ordinances cannot be enforced (189).

\section{Conclusion}

By casting Hazleton's legislation as an attack on society's most vulnerable people, Judge Munley drew upon the proud tradition of the civil-rights movement. Hazleton, from this perspective, had deemed some of its residents "undesirable" and used its law-making power to encourage them to leave. The city's Illegal Immigration Relief Act thus bore a passing resemblance to the Jim Crow laws of an earlier era and the race hatred that underlay them. On the opposing side in that struggle, and this one, were the Constitution, and dedicated lawyers and judges determined to uphold its principles. The moral basis for the decision was finally clear.

But should Hazleton's motivations be judged so harshly? Judge Munley's opinion entirely avoids the dilemmas that face small communities in adjusting to large numbers of new residents. It says nothing about the failure of the federal government to more actively support the integration of immigrants or to recognize in its own programs the ineffectiveness of its control over unauthorized entry. The 1986 legislation had combined legalization with sanctions as a quid pro quo. Hazleton's leaders may have been frustrated that the federal government had not kept its bargain or even acknowledged the problems its policies had created. Even reading Hazleton's legislation in a more critical light, it can at least be said that violence had been (for the most part) avoided, something that was not true in an earlier era when vigilantism was common.

Clearly there are more dimensions to this conflict than Judge Munley addressed in Lozano v. Hazleton. Litigation confines conflict, domesticating it, and channelling energies into limited, particularized inquiry. The intervention of skilled, highly paid legal professionals with no personal stake in the conflict is thought to bring rationality and calm to the scene. ${ }^{13}$ Recall that Judge Munley spoke of the "excessive zeal" of Hazleton's leaders without admitting to any feelings on his own part. I suggest, however, that Judge Munley revealed in his long opinion a certain zeal for a legally constrained justice. He deployed a judge's usual stratagems to depersonalize judgment and render it "blind." He put law at the centre of his response to the litigants, de-contextualizing the dispute from the particular personalities involved. Most significantly, he drew from the well of constitutional ideals to suggest the underlying values at stake in this controversy and the need for a just resolution.

The decision in Lozano v. Hazleton will not settle the issues at stake, nor will the appeal, whatever its outcome. Legal decisions frame disputes too narrowly to satisfy the yearning for justice that moves people who believe they have suffered serious harm. Jenness (2001) has observed the same tendency in the wording of civil-rights guarantees, which, by custom and convenience, are set forth in generic terms that mask the pain and outrage that prompted their adoption. A judicial narrative is, of course, much more nuanced and detailed than a statutory prohibition. The successful 
judicial narrative uses the tools of law to build a final result, while subtly suggesting affiliation with the broader contours of justice.

Were opinion-writing a cloistered professional activity, judicial strategies for depersonalizing their decisions would be of only passing interest. In American political culture, however, these narratives play a more significant role. Judicial decisions provide rhetorical heft in public debate, and even more importantly, they subtly shape ways of framing issues and make them seem familiar and defensible. Consider for example, the irritating retort: "What part of 'illegal' don't you understand?" The implication here is that law provides a ready answer to the question of how to respond to people who have settled in communities without authorization. The belief that law can be divorced from moral concerns is false, and dangerously so. But this belief is widespread because legal habits of thought are pervasive in the United States. De Tocqueville noted, and praised, this tendency over a century ago; he should perhaps have viewed it with a more critical eye.

Whether or not one agrees with Judge Munley's opinion in Lozano v. Hazleton, it is important not to be seduced by its methodology. Judicial decisions are a necessary element in the resolution of social conflict, but they are not a sufficient guide to moral choice for concerned observers. The difficult questions raised by enforcing immigration laws against settled residents require an expedition into moral territory that lawyers and judges — and many of the rest of us_-tend to avoid.

\section{Notes}

1 (No. 06-CV-01586-JMM (M.D. Penn. 2006, 153 DLR A-3, 8/9/07). The page quotes in the sections that follow are taken from the initial citation. The case is currently under appeal in the U.S. Court of Appeals for the Third Circuit in Philadelphia. Oral argument occurred on October 30, 2008. As of this writing, a decision on Hazleton's appeal has not been reached.

2 The Third Circuit U.S. Court of Appeals has the case under appeal (Lozano v. Hazleton, Pa. (No. 07-3531; 22 DLR A-7 2/4/08). The Eighth Circuit is hearing an appeal from a districtcourt decision that upheld a Valley Park, Missouri city ordinance similar to Hazleton's (Gray v. Valley Park, Mo. 2008 U.S. Dist. LEXIS 7238 (E.D. Mo. Jan. 31 2008). See 22 DLR A-7, 2/4/08. The Ninth Circuit has decided not to rehear its September 17, 2008 decision upholding Arizona's employer sanctions law (Chicanos por la Causa Inc. v. Napolitano, $9^{\text {th }}$ Cir. No. 07-17272, 182 DLR AA-1, 9/19/08, denial of re-hearing 3/9/09). The Tenth Circuit is reviewing a district court's preliminary injunction that postponed enforcement of portions of an Oklahoma law that involved employer sanctions. A federal district court recently ruled against an unusual Illinois law that would have barred employers from using the federal employee verification system, E-Verify (No. 07-3261). In Villas at Parkside Partners v. The City of Farmers Branch (2008 U.S. Dist. LEXIS 42452 (N.D. Tx May 28, 2008) a federal judge granted a permanent injunction barring enforcement of a city statute that required proof of citizenship prior to renting or leasing residential property on grounds of federal pre-emption.

3 While thefts and drug-related crime have increased on a per capita basis since 2000, rapes, robberies homicides, and assaults have decreased. Gaiutra Bahadur, "Hazleton gets a jolt it didn't want,” Philadelphia Inquirer, September 20, 2006, p. A-02.

4 Barletta visited Washington to suggest that the Department of Homeland Security establish an Immigration Control Enforcement (ICE) office in the Hazleton area. He participated in a forum at Notre Dame University on October 12, 2007 as one of three prominent speakers on immigration. 


\section{Doris Marie Provine}

5 This website features a picture of Mayor Barletta and his call for donations, which can be sent c/o the mayor. http://www.smalltowndefenders.com/public/

6 This document, prepared by the State of Pennsylvania, but based on U.S. Census Bureau figures (Population Division) can be found (along with other demographic information) on the Hazleton Chamber of Commerce, Greater Hazleton Community Profile.

http://www.hazletonchamber.org/images/stories/pdf/profile.pdf. See also a demographic profile prepared by Pennsylvania for cities in the state: http://www.idcide.com/citydata/pa/hazleton.htm

7 Savageau's Places Rated Almanac ranks the Hazleton, Scranton, Wilkes-Barre area below the national average, with Hazleton offering less expensive living than its rivals. This information is quoted in the Greater Hazleton Community Profile, footnote 6.

8 One observer described Hazleton in 1837 as a "patch" with a few houses, a hotel, and an inn. The determined efforts of Ario Pardee to bring this new type of coal to market had a major impact on Hazleton, which incorporated as a city in December 1891, with 14,000 residents. In 1899 it attracted a French manufacturer, the Duplan Silk Corporation, which eventually employed 2000 residents, displacing coal as the city's major industry. That plant closed in 1953, leaving a relatively weak local economy fueled by manufacturing and tourism. See Our Roots: Hazleton Area History retrieved on 4/12/09 at: http://www.hazletonhistory.8m.com/pardee.htm

9 Letter to Louis Barletta, August 15, 2006 offering to settle without cost if the City would revoke the ordinance and promise not to enact others attempting to regulate immigration. Fifteen plaintiffs' lawyers, representing nine firms and associations, signed the letter. Mayor Barletta received a letter in July from many of the same attorneys opposing the statute and arguing that the proposed ordinance was unlawful. Letters on file with the author.

10 P. 14, Lozano v. Hazleton. \# 3:06cv1586. Judge Munley is quoting from Simon v. Eastern Kentucky Welfare Rights Org., 426 U.S. 26 at 38 (1976). The doctrine of standing has few clear guidelines. It is fundamentally pragmatic, based on the idea that courts should not get involved in disputes without the justification of an injured party demanding relief. The courts often state this requirement in constitutional terms, citing the Constitution's grant of jurisdiction to courts for "cases and controversies" arising under Article III, Section 2.

11 Jane Doe 1 v. Merten, 219 F.R.D. 387 (E. D. Va. 2004). A May, 2007 New York Employment Law Letter discusses this dilemma in the context of Fair Labor Standards Act claims by undocumented immigrants, suggesting that inquiry into a worker's immigration status would likely intimidate workers from filing valid claims. Such inquiries should therefore be avoided. (Michael DiChiara, vol. 14, issue 5, May, 2007).

${ }^{12}$ Plyler v. Doe, 457 US 202 (1982) at p. 236. This case overturned a state law excluding undocumented alien children from public schooling in Texas. It is currently under attack by conservatives who see it as an obstacle to their efforts to deter unauthorized immigration.

13 The Plaintiff lawyers requested $\$ 2,333,351.50$ for time and resources spent on the case, citing fees of up to $\$ 410 /$ hour for some of the attorneys. See Plaintiffs' Petition for Attorneys’ Fees and Costs, Pedro Lozano v. City of Hazleton, Civil Action No. 3:06-cv01586-JMM. At least one Wilkes-Barre law office touted its membership on the team in advertizing its services

http://www.poconoimmigration.com/id11.html.

\section{References}

Bahadur, G. (2006, September 20). Hazleton gets a jolt it didn’t want. Philadelphia Inquirer, A-02.

Cover, R. (1985). Violence and the word. Yale Law Journal, 95, 1848.

Decker, S., Lewis, P., Provine, D.M., \& Varsanyi, M. (2009). On the frontier of local law enforcement: Local police and federal immigration law. Sociology of Crime, Law, and Deviance, 13, 263-78.

Delgado, R. (2007). The Law unbound! A Richard Delgado reader. New York, NY: Paradigm.

De Tocqueville, A. (2003). Democracy in America. New York, NY: Penguin Classics. (Original work published 1835) 
Epp, C. R. (1998). The rights revolution: Lawyers, activists, and Supreme Courts in comparative perspective. Chicago, IL: University of Chicago Press.

Ewick, P., \& Silbey, S. (1998). The common place of law: Stories from everyday life. Chicago, IL: University of Chicago Press.

Fish, S. (1991). Law wishes to have a formal existence. In A. Sarat \& T. R. Kearns (Eds.). The fate of the law. Ann Arbor, MI: University of Michigan Press.

Fitzpatrick, P., \& Tuitt, P. (2004). Critical beings: Law, nation, and the global subject. Aldershot, UK: Ashgate.

Jenness, V. (2001). The hate crime canon and beyond: A critical assessment. Law and Critique, 12, 279308.

Kairys, D. (1998). The politics of law: A progressive critique. New York, NY: Basic Books.

Kelly, N. (2008). (2008, September 10). Legal minds at odds over immigration edicts. Retrieved from http://www.journalgazette.net/apps/pbcs.dll/article?AID=/20080910/NEWS07/809100301/

Kmiec, K. (2004). The origin and current meanings of judicial activism. California Law Review, 2004, 1442-1480.

Lipkin, R. J. (2008). We are all judicial activists now. Cincinnati Law Review. 77, 182-238.

Lozano v. Hazleton (2007). No. 06-CV-01586-JMM (M.D. Penn. 2006, 153 DLR A-3, 8/9/07).

McCann, M. (2006). Law and social movements: Contemporary perspectives. Annual Review of Law and Social Science, 2, 17-38.

Merry, S. (1990). Getting justice and getting even. Chicago, IL: University of Chicago Press.

Migration Policy Institute. (2007). Top 10 migration issues of 2007: Issue \#7: US cities face legal challenges, and all 50 states try their hand at making immigration-related laws. Retrieved from http://www.migrationinformation.org/Feature/display.cfm?id=659

National Conference of State Legislatures. (2009). State laws related to immigrants and immigration in 2008. Retrieved from http://www.ncsl.org/programs/immig/2008StateLegislationImmigration.htm

Nielsen, L. B. (2000). Situating legal consciousness: Experiences and attitudes of ordinary Americans. Law \& Society Review, 34(4), 1055-90.

O’Barr, W. \& Conley, J. (2004). Back to the Trobriands: The enduring influence of Malinowski's crime and custom in savage society. Journal of Law and Social Inquiry, 27(4), 847-74.

O’Scannlain, D. F. (2009). On judicial activism. Open Spaces Quarterly. Retrieved from, http://www.open-spaces.com/article-v3n1-oscannlain.php

Pender, S. (2007). An interview with David Harvey. Studies in Social Justice, 1(1),14-22.

Powell, J. H. (2008). Constitutional conscience: The moral dimension of judicial decision. Chicago, IL: University of Chicago Press.

Powell, M., \& García, M. (2007). Pa. city puts illegal immigrants on notice. Retrieved from http://www.msnbc.msn.com/id/14463098/

Preston, J. (2008, February 10). In reversal, courts uphold local immigration laws. New York Times. Retrieved

from http://www.nytimes.com/2008/02/10/us/10immig.html?_r=1\&pagewanted=print\&oref=slogin

Provine, D. M. (2005). Judicial activism and American democracy. In K. L. Hall \& K. T. McGuire (Eds.) The judicial branch. New York, NY: Oxford University Press.

Ramakrishnan, K. S., \& Wong, T. (2007). Immigration policies go local: The varying responses of local governments to undocumented immigrants. Retrieved from http://www.law.berkeley.edu/files/bclbe/RamakrishnanWongpaperfinal.pdf

Sarat, A. \& Scheingold, S. (2001). Cause lawyering and the State in the global era. New York, NY: Oxford University Press.

Sarat, A. (2004). Crossing boundaries: From disciplinary perspectives to an integrated conception of legal scholarship. In A. Sarat (Ed.) Law in the Liberal Arts. Ithaca, NY: Cornell University Press.

Savageau, D. (1999). Places rated almanac. New York: Wiley.

Scheingold, S. (1967) The politics of rights: Lawyers, public policy and political change. (1 $1^{\text {st }}$ ed.) New Haven, CT: Yale University Press.

Shiffrin, S. H. (1989). The first amendment, democracy, and romance. Cambridge, MA: Harvard University Press.

Sunstein, C. R. (1996). Legal reasoning and political conflict. New York, NY: Oxford University Press.

Tichenor, D. (2002). Dividing lines: The politics of immigration control in America. Princeton, NJ: Princeton University Press.

Tyler, T. (2006). Why people obey the law. Princeton, NJ: Princeton University Press.

Unger, R. (1996). What should legal analysis become? New York, NY: Verso. 